\title{
Assessment of Knowledge of Hypertension among Patients with Mental Illness Approaching a Community Psychiatry
} Service

\author{
Shubh M Singh ${ }^{1}$, Chandrima Naskar ${ }^{2}$, Yogender Malik ${ }^{3}$, Shantanu Shukla ${ }^{4}$, Vikas Suri ${ }^{5}$
}

\begin{abstract}
Aim: Hypertension is a common chronic disease which progressively and permanently damages target organs, leading to life-threatening complications and death. A lack of knowledge about hypertension may be detrimental to efforts at prevention and control of hypertension. Patients with mental illness are known to have greater cardiometabolic morbidity and mortality. This study aimed to assess the knowledge regarding hypertension among patients with mental illness in community settings of Punjab and Haryana.

Materials and methods: One hundred eighty patients attending the community psychiatry clinic of at two rural locations of Haryana (Naraingarh and Raipurrani) and Punjab (Kharar and Nandpurkalor) were included. All patients were assessed for knowledge about hypertension by using a 29-item-adapted Hindi version of the patient-administered Hypertension Knowledge-Level Scale (HK-LS). Each correct response was marked as 1 , and incorrect or no response was marked 0.

Results: In the study population, the mean knowledge scores obtained was 20.87 (SD: 2.51 ; range: 14-28). A history of hypertension was available in $22.2 \%$ of participants. There was no statistical difference of the score on the knowledge questionnaire between those with and without hypertension.

Conclusion: Results indicate an appreciable level of knowledge about hypertension in our study population. However, efforts at hypertension screening and education should continue.

Clinical significance: The levels of knowledge of hypertension in patients with psychiatric disorders suggest that it may be feasible to study whether lifestyle modifications are actually in place and whether these are feasible.

Keywords: Attitude, Awareness, Community psychiatry, Hypertension, Knowledge, Mental illness, Noncommunicable disease.

Journal of Postgraduate Medicine Education and Research (2020): 10.5005/jp-journals-10028-1344
\end{abstract}

\section{A IM}

Hypertension is a chronic disease and a major public health issue which progressively damages multiple end organs, increases cardiovascular mortality, and leads to outcomes like cerebrovascular accidents and renal failure. ${ }^{1,2}$ The coexistence of mental disorders with chronic illnesses like hypertension, diabetes mellitus, and dyslipidemia is well known. ${ }^{3}$ Cardiovascular diseases are a major coexisting problem and substantial cause of morbidity in patients with mental disorders. However, hypertension is a modifiable risk factor, and patients' awareness and knowledge can be an important mediator of hypertension management to prevent these complications. ${ }^{4-6}$ A lack of knowledge and unfavorable attitude about hypertension negatively influences patients' behavior and is a major obstacle in controlling the disease. Untreated hypertension associated with noncompliance is related to poor psychosocial functioning, poor self-care, and an unhealthy lifestyle which increases the probability of resistance to treatment, frequent relapse and hospitalization of patients with mental illness. The above review shows that there are gaps in knowledge in existing literature regarding the extent of knowledge about hypertension among patients suffering from mental illness. This study aimed to assess the knowledge of hypertension in patients with mental illness in community settings.

\section{Materials and Methods}

The study to assess knowledge and attitude toward hypertension among patients with mental illness was a cross-sectional descriptive

\begin{abstract}
${ }^{1-4}$ Department of Psychiatry, Postgraduate Institute of Medical Education and Research, Chandigarh, India

${ }^{5}$ Department of Internal Medicine, Postgraduate Institute of Medical Education and Research, Chandigarh, India

Corresponding Author: Shubh M Singh, Department of Psychiatry, Postgraduate Institute of Medical Education and Research, Chandigarh, India, Phone: +91 2147483647, e-mail: shubhmohan@gmail.com

How to cite this article: Singh SM, Naskar C, Malik Y, et al. Assessment of Knowledge of Hypertension among Patients with Mental Illness Approaching a Community Psychiatry Service. J Postgrad Med Edu Res 2020;54(1):8-11.
\end{abstract}

Source of support: Nil

Conflict of interest: None

study carried out in two rural locations of Haryana (Naryangarh and Raipurrani) and two in Punjab (Boothgarh and Nandpurkalor). Patients with any psychiatric diagnosis attending the outpatient services of primary healthcare center in these community psychiatric services were approached, and 180 patients were recruited through purposive sampling. There are various instruments for assessing the knowledge and attitude toward hypertension. However, we chose to adapt the patient-administered Hypertension Knowledge-Level Scale (HK-LS) in Hindi. Hypertension Knowledge-Level Scale was developed in 2012 and has satisfactory reported reliability and validity, with a Cronbach's alpha quotient of 0.82 and a test-retest validity of $r=0.79 .^{7}$ This instrument was chosen by the authors as

(0) The Author(s). 2020 Open Access This article is distributed under the terms of the Creative Commons Attribution 4.0 International License (https://creativecommons. org/licenses/by-nc/4.0/), which permits unrestricted use, distribution, and non-commercial reproduction in any medium, provided you give appropriate credit to the original author(s) and the source, provide a link to the Creative Commons license, and indicate if changes were made. The Creative Commons Public Domain Dedication waiver (http://creativecommons.org/publicdomain/zero/1.0/) applies to the data made available in this article, unless otherwise stated. 
one which was most appropriate to the Indian context. However, we removed items $5,6,16$, and 17 . Item 5 was removed because the response as mentioned in the questionnaire was not considered correct. Item 6 was not easily understandable. Items 16 and 17 were not appropriate for vegetarians. In addition, after consultation between the authors, certain items were added to improve the comprehensiveness of the questionnaire. This was done on basis of clinical experience, existing literature, and items mentioned in other questionnaires. These included items 1, 14, 15, and 21-29. The 29-item questionnaire was circulated among the authors for finalizing the English version. Two bilingual colleagues were asked to translate this English questionnaire into Hindi language which the two translators then reconciled to get a commonly accepted version. This was thereafter back-translated into Hindi. These steps were found to be acceptable. A prefinal version was piloted to check for acceptability and understandability in 20 patients. Using the suggestions, a final 29-item Hindi version was arrived at. The questionnaire has true/false responses. Each correct response was scored as 1, and incorrect response was scored as 0 . In this scale, knowledge and attitude are assessed under six areas, namely definition (items 1-3), medical treatment (items 22, 23, 26, 29), lifestyle changes (items 21, 24, 25, 27, 28), diet (items 8-15), drug compliance (items 4-7), and complications (items 16-20). We tried to keep the items as close to colloquial usage as possible to improve ease of understanding.

An attempt was made to assess areas of least and most knowledge deficiency and also to see if there was any difference in knowledge and attitude toward hypertension among those who were already under treatment for same and those who were not.

\section{Results}

Among the 180 patients studied, $55 \%$ were male and the mean age of the participants was 43.9 years. A total of $84.4 \%$ were residents of rural localities, $87.2 \%$ belonged to middle socioeconomic status, $87.2 \%$ were married at the time of the study, and on an average the participants had received 9 years of education. Among the diagnoses, depressive disorders of any severity were the most common illness, found in $61.7 \%$ of the participants followed by Anxiety disorder in $16.1 \%$. These were clinical diagnoses arrived at in the clinic as per usual protocols. The sociodemographic and clinical distribution of the study population is elaborated in Table 1.

Table 1: Sociodemographic profile of the population studied $(n=180)$

\begin{tabular}{ll}
\hline Variable & Mean (SD)/frequency \\
\hline Mean age in years (SD) & \\
Males & $45.30(15.50)$ \\
Females & $42.22(14.13)$ \\
Total population & $43.9(\mathrm{SD}=14.94)$ \\
Gender (male) & $55 \%$ \\
Locality (rural) & $84.4 \%$ \\
Marital status (married) & $87.2 \%$ \\
Years of education & $9(\mathrm{SD}=4.08)$ \\
Middle socioeconomic status & $87.2 \%$ \\
Broad psychiatric diagnosis & \\
Depressive, anxiety, and somatoform & $61.7 \%$ \\
disorders & \\
Bipolar disorder & $5 \%$ \\
Schizophrenia and other psychotic disorders & $12.2 \%$ \\
Others & $21.1 \%$ \\
\hline
\end{tabular}

The mean age of those diagnosed with hypertension was 54.80 years $(S D=15.04)$ compared to those without hypertension which was 40.80 years $(S D=13.42), p=0.11$.

On assessing the number of correct responses to each of the 29 questions, the average score among all the participants came to be 20.87 (SD: 2.51; range: 14-28). The highest score was noted on question no. 28 where around $98 \%$ of the participants agreed that regular physical exercise might help in controlling hypertension. The least score was found on question 9 where only $28 \%$ participants responded correctly regarding knowledge about alcohol use in hypertensive patients. To compare the knowledge in the six identified domains, high knowledge (>90\% participants answered correctly) was noted regarding complications and lifestyle changes. Knowledge was moderate to poor in areas of definition, medical treatment, drug compliance, and diet. The details of the percentage of participants responding correctly to each of the 29 items are presented in Table 2.

In this current study, though $22.2 \%$ of the participants were found to have been diagnosed with hypertension at some point before the study. The mean scores of the questionnaire in the patients with hypertension vs those without hypertension was $21.00(\mathrm{SD}=2.36)$ and $20.83(\mathrm{SD}=2.55)(p=0.39)$, respectively. There were no significant differences between the diagnostic groups with regard to the knowledge of hypertension and on individual items.

\section{Conclusion}

This study was conducted in a sample of patients with mental illness as encountered in the community. We assessed the knowledge of hypertension in this population and also tried to compare the results between those who knew they had hypertension in addition to mental illness and those who did not.

Our study had multiple limitations. The instrument used was an adaptation of an existing scale, and some changes were made to make it more culturally relevant. The scale was considered appropriate in our context as per the authors. However, the resultant scale was not formally statistically validated. We used purposive sampling, and psychiatric diagnosis were made based on clinical assessment only, but considering this as a pilot study in the area of assessment regarding knowledge and attitude regarding hypertension in rural population suffering from mental illness, it showed interesting findings.

Studies in the community or hospital settings with other groups of patients have shown average to good levels of knowledge regarding hypertension with some exceptions. ${ }^{8-10}$ Various studies have shown higher prevalence of cardiovascular morbidity and mortality in patients with severe mental illness. However, a recent study conducted in this department has shown a high prevalence of hypertension and other noncommunicable disease risk factors in people with common mental disorders in the community as well. ${ }^{11}$ Proper knowledge regarding hypertension can be an important factor in self-management and prevention of hypertension in patients with mental illness. In our study, the level of knowledge was found to be fairly adequate regarding the definition and consequences of hypertension. Knowledge was somewhat lacking in the areas of preventive lifestyle changes and recommended treatment. Contrary to expectation, there were statistically insignificant differences between knowledge deficits in known hypertensive patients vs those who did not have hypertension. No similar studies assessing patients with psychiatric disorders could be found. Similar studies in general healthcare in India have shown 
Table 2: Intraoperative findings

\begin{tabular}{|c|c|c|}
\hline & & (\%) of correct response \\
\hline 1 & $\begin{array}{l}\text { भारत सरकार के मानदंडों के अनुसार, एक वयस्क व्यक्ति (18 वर्ष या उस से अधिक) को उच्च रक्तचाप (हाई } \\
\text { blood pressure/BP) से पीड़ित माना जाता है यदि उसका बीपी (BP) 140/90 (Systolic/diastolic) मिमी mercury } \\
\text { से अधिक है }\end{array}$ & 81.11 \\
\hline 2 & बढ़ा हुआ डायस्टोलिक BP भी बढ़ा हुआ BP (हाई BP) दर्शाता है & 52.78 \\
\hline 3 & बढ़ा हुआ डायस्टोलिक या सिस्टोलिक रक्तचाप बढ़ा हुआ BP (high BP) दिखाता है & 81.67 \\
\hline 4 & हाई $\mathrm{BP}$ की दवा (जब डॉक्टर के लेने को कहा हो) नियमित रूप से प्रतिदिन लेनी चाहिए & 78.89 \\
\hline 5 & हाई BP की दवा तभी लेनी चाहिए जब अस्वस्थ महसूस हो & 34.44 \\
\hline 6 & अगर हाई BP दवा के इलाज से ठीक हो जाए तो जीवन शैली बदलने की आवश्यकता नहीं है & 36.11 \\
\hline 7 & हाई BP बढ़ती उम्र के साथ हो जाता है, इलाज की ज़रुरत नहीं है & 28.33 \\
\hline 8 & हाई $\mathrm{BP}$ का मरीज़ ज़्यादा नमक वाला खाना खा सकता है अगर वो नियमित दवा लेता हो & 30.56 \\
\hline 9 & हाई BP का मरीज़ मन चाही मात्रा में शराब पी सकता है & 27.22 \\
\hline 10 & हाई BP के मरीज़ को सिगरेट नहीं पीनी चाहिए & 83.33 \\
\hline 11 & हाई $\mathrm{BP}$ के मरीज़ को फल और सब्ज़ियां ज़्यादा खानी चाहिए & 92.78 \\
\hline 12 & हाई BP के मरीज़ को को तला हुआ खाना चाहिए & 28.89 \\
\hline 13 & हाई $\mathrm{BP}$ के मरीज़ को भूना या उबला हुआ खाना खाना चाहिए & 85.00 \\
\hline 14 & बिना मलाई वाल दूध हाई BP के मरीज़ के लिए उपयुक्त हैं & 92.78 \\
\hline 15 & फुल क्रीम दूध और मक्खन इत्यादि हाई BP के मरीज़ के लिए उपयुक्त हैं & 43.33 \\
\hline 16 & बढे हुए रक्तचाप (हाई BP) का सही इलाज न होने की हालत में अकाल मृत्यु हो सकती हैं & 91.11 \\
\hline 17 & बढे हुए रक्तचाप (हाई BP) का सही इलाज न होने की हालत में दिल की बिमारी जैसे हार्ट अटैक हो सकती है & 97.22 \\
\hline 18 & बढे हुए रक्तचाप (हाई BP) का सही इलाज न होने की हालत में अधरंग हो सकता है & 87.22 \\
\hline 19 & बढे हुए रक्तचाप (हाई BP) का सही इलाज न होने की हालत में गुर्दे ख़राब हो सकते है & 78.21 \\
\hline 20 & अगर इलाज नहीं किया जाता है तो हाई BP के मरीज़ को दिखाई देने में/नज़र में तकलीफ पैदा हो सकती हैं। & 92.22 \\
\hline 21 & सभी वयस्कों (18 वर्ष या उस से अधिक) को समय-समय पर उच्च रक्तचाप (हाई BP) के लिए जांच करानी चाहिए & 92.78 \\
\hline 22 & गर्भवती महिलाएं उच्च रक्तचाप (हाई BP) विकसित कर सकती हैं & 89.44 \\
\hline 23 & मधुमेह (डायबिटीज) के मरीज़ो को अक्सर उच्च रक्तचाप (हाई $\mathrm{BP}$ ) होता है & 93.89 \\
\hline 24 & मानसिक तनाव BP बढ़ा सकता है & 93.33 \\
\hline 25 & नींद की समस्या का उच्च रक्तचाप (हाई BP) पर कोई प्रभाव नहीं पड़ता है & 60.00 \\
\hline 26 & $\begin{array}{l}\text { ज्यादातर लोग बता सकते हैं कि उनका रक्तचाप (BP) अधिक है क्योंकि उन्हें बेचैनी, सर में दर्द जैसे लक्षणों का } \\
\text { अनुभव होता है }\end{array}$ & 73.89 \\
\hline 27 & वजन घटाने से उच्च रक्तचाप (हाई BP) में कमी आ सकती है & 92.13 \\
\hline 28 & नियमित शारीरिक व्यायाम से उच्च रक्तचाप (हाई BP) में कमी हो सकती है & 97.78 \\
\hline 29 & उच्च रक्तचाप (हाई $\mathrm{BP}$ ) से पीड़ित व्यक्ति को यदि आवश्यक हो तो आजीवन दवा लेनी पड़ सकती है & 72.22 \\
\hline
\end{tabular}

that patients usually have good knowledge of hypertension., ${ }^{9,12}$ Our results show that this is true for patients with mental illness as well. A possible reason could be that owing to the high prevalence of hypertension in India, almost everyone has heard of it or knows someone who is on treatment for hypertension. Combined with public health messaging, people in India in at least healthcare settings have good knowledge with regard to hypertension. This is true even for those who do not have hypertension. However, the continuing burden of cardiovascular morbidity and mortality shows that this knowledge does not translate into the prevention of hypertension or the prevention of consequences of hypertension. Further studies are needed to assess the knowledge of hypertension among the unaffected in the community and also to find out the reasons why knowledge does not lead to behavioral change which can go a long way in the prevention of the consequences of hypertension.

This study shows that there is a necessity for providing the patients attending the rural community clinics with basic education regarding lifestyle changes and importance of regular screening for hypertension during the course of their treatment for mental illnesses as the prognosis of both are linked to one another. Need for proper adherence to anti-hypertensives is another area that needs to be emphasized on while treating patients as they tend to strongly believe that medications are only necessary when there are premonitory signs of hypertension like headache, weakness, and palpitations. Thus, though the general level of knowledge seems 
somewhat satisfactory, there are areas of deficit that can be further improved by providing education regarding the illness.

\section{References}

1. Kearney PM, Whelton M, Reynolds K, et al. Global burden of hypertension: analysis of worldwide data. Lancet 2005;365(9455): 217-223. DOI: 10.1016/S0140-6736(05)17741-1.

2. Oliveria SA, Chen RS, McCarthy BD, et al. Hypertension knowledge, awareness, and attitudes in a hypertensive population. J Gen Intern Med 2005;20(3):219-225. DOI: 10.1111/j.1525-1497.2005. 30353.x.

3. Zolezzi M, Abdulrhim S, Isleem N, et al. Medical comorbidities in patients with serious mental illness: a retrospective study of mental health patients attending an outpatient clinic in Qatar. Neuropsychiatr Dis Treat 2017;13:2411-2418. DOI: 10.2147/NDT. S141448.

4. Magadza C, Radloff SE, Srinivas SC. The effect of an educational intervention on patients' knowledge about hypertension, beliefs about medicines, and adherence. Res Soc Adm Pharm 2009;5(4): 363-375. DOI: 10.1016/j.sapharm.2009.01.004.

5. Oskay EM, Onsuz, Topuzoglu A. Assesment of hypertension knowledge, attitude and throught of policyclinic patients at primary health care center in Izmir. J Adnan Menderes Univ Med Fac 2010;11:3-9.
6. Scalco AZ, Scalco MZ, Azul JBS, et al. Hypertension and depression. Clinics 2005;60(3):241-250. DOI: 10.1590/S1807-59322005000300010.

7. Erkoc SB, Isikli B, Metintas S, et al. Hypertension knowledge-level scale (HK-LS): a study on development, validity and reliability. Int J Environ Res Public Health 2012;9(3):1018-1029. DOI: 10.3390/ijerph9031018.

8. Busingye D, Arabshahi S, Evans RG, et al. Factors associated with awareness, treatment and control of hypertension in a disadvantaged rural indian population. J Hum Hypertens 2017;31(5):347-353. DOI: 10.1038/jhh.2016.85.

9. Gupta RK, Hussain S, Parveen Z, et al. Does being under treatment improve knowledge attitude practice for hypertension: a hospitalbased study from north india. J Fam Med Prim Care 2017;6(2):279-283. DOI: 10.4103/2249-4863.220040.

10. Joseph N, Chiranjeevi M, Sen S, et al. Awareness on hypertension and its self-management practices among hypertensive patients attending outreach clinics of a medical college in south india. Kathmandu Univ Med J KUMJ 2016;14(55):202-209.

11. Singh SM, Surenderan I, Jain S, et al. The prevalence of noncommunicable disease risk factors in community-living patients with psychiatric disorders: a study from North India. Asian J Psychiatry 2019;41:23-27. DOI: 10.1016/j.ajp.2019.03.004.

12. Mounica B. Study of knowledge, attitude and practice of general population of Guntur towards silent killer diseases: hypertension and diabetes. Value Health 2015;18(7):A398. DOI: 10.1016/ j.jval.2015.09.907. 